\title{
Geochemistry and Industrial Applications of Brown Coals of the Ogwashi-Asaba Formation in Parts of Anambra State, Nigeria
}

\author{
Ogechukwu Caroline Onyemesili* \\ Chukwuemeka Frank Raluchukwu Odumodu* \\ Mmesomma Janefrancis Adoro \\ Department of Geology, Chukwuemeka Odumegwu Ojukwu University, P.M.B. 02, Uli, Anambra State
}

The research is financed by Tetfund IBR.

\section{Abstract}

Geochemical studies have been carried out on brown coal of the Ogwashi-Asaba Formation in parts of Anambra State, Nigeria, using proximate and ultimate analytical results to evaluate its potentials for industrial utilization. An understanding of the physico-chemical characteristics such as moisture content , volatile matter content, fixed carbon content, and ash content are essential for establishing the quality of the coal. The chemical analysis of the brown coal samples results suggest that fixed carbon varies from 1.51 to $37.50 \mathrm{wt} \%$, moisture content varies from 2.40 to $39.80 \mathrm{wt} \%$, volatile matter varies from 2.44 to $39.92 \mathrm{wt} \%$, and ash content ranges from 6.60 to $70.75 \mathrm{wt} \%$, carbon content ranges from $11.59 \mathrm{wt} \%$ to $59.33 \mathrm{wt} \%$, oxygen content ranges from 0.06 to $13.87 \mathrm{wt} \%$, hydrogen content ranges from 0.13 to $4.59 \mathrm{wt} \%$, sulfur content varies from 0.04 to $2.48 \mathrm{wt} \%$ and the nitrogen content varies from $1.30 \%$ to $1.85 \mathrm{wt} \%$. The high-moisture content poses several challenges for the utilization of lignite, because it lowers the energy density of the fuel and makes its transportation uneconomic over long distances. The analytical results show that the coal cannot be employed in the steel industry for the generation of substantial heat for the working of the furnace but can be used as a steam coal. Proximate analysis and calorific data suggest that the coal belongs to the lowest rank i.e. lignite. The brown coal is less hazardous to the ecosystem because of its significantly low sulfur and nitrogen contents. Based on the results of the study, the brown coal can be used for power generation, gasification, production of industrial chemicals and cement production.

Keywords: Coal, Proximate Analysis, Ultimate Analysis, Calorific values

DOI: $10.7176 / \mathrm{JNSR} / 12-12-03$

Publication date: June $30^{\text {th }} 2021$

\section{Introduction}

Nigeria possesses enormous fossil fuel resources, including coal, lignite, tar sand, oil and gas. Whereas exploration and production efforts have largely focused on oil and gas, the nation's coal and lignite resources remain largely un-utilized. Nigeria's lignite deposits occur within the Eocene - Oligocene successions (Oboh-Ikuenobe et al, 2005), outcropping in a 15 - $17 \mathrm{~km}$-wide strip that stretches NW-SE from Asaba in Delta State, through Onitsha, Ozubulu and Nnewi, into Abia State and beyond (Nwajide, 2013).

Several geological studies have been carried out on the lignite-bearing Ogwashi-Asaba Formation since its discovery by the Mineral Survey of Southern Nigeria in 1907. Parkinson (1907) called the formation the "lignite series" while Wilson (1925) referred to it as the "Lignite Group". Earlier work on the formation includes the studies by Du Preez (1945)' Simpson, (1955)' De Swardt and Piper (1957), Short and Stauble (1967). Okezie and Onuogu (1985). The formation name Ogwashi-Asaba Formation was formalized by Reyment (1965). Most previous studies on the formation were based on stratigraphy and sedimentology (Bassey and Eminue, 2012: Onyekuru et al, 2019), age and depositional environment (Okezie and Onuogu, 1985; Chene et al, 1978; Umeji, 2003), source rock evaluation and thermal maturation (Olobaniyi and Ogala, 2011: Ogala, 2011: Akande et al, 2015: Okeke and Umeji, 2018), provenance and depositional settings, geochemistry(Nwadinigwe, 1991; Okezie and Onuogu, 1985: Ogala, 2012), and industrial uses (Ahiarakwem and Opara, 2012, Odumodu and Onyemesili, 2021).

In the Onitsha-Nnewi axis, this relatively unexplored deposit is reported to exceed 4 metres in thickness (Okezie and Onuogu, 1985). The thickness of the lignite seams suggests the presence of a substantial quantity of the resource, but the paucity of comprehensive and reliable geological and geochemical data may have contributed to its non-exploitation. This research is focused on the geochemical characteristics of the lignite deposits in Anambra State with intent to suggest its best applications. Lignite's have various industrial applications which are dependent on the specific physical and chemical properties. It is therefore necessary to carry out detailed physical and chemical characterization of the lignite's to in order to assess their quality and suggest their potential economic value.

\subsection{Geological Setting}

The area of study lies within longitudes $5^{\circ} 57^{\prime} \mathrm{E}$ to $7^{\circ} 00^{\prime} \mathrm{E}$ and latitudes $5^{\circ} 50^{\prime} \mathrm{N}$ to $6^{\circ} 06^{\prime} \mathrm{N}$ as indicated in the geological map (Fig. 1), which is a part of the Niger Delta Basin of Nigeria. The position of the Ogwashi-Asaba Formation within the stratigraphic sequence in southeastern Nigeria is presented in Table 1. The lithostratigraphy 
of Imo Formation, Ameki Group, Ogwashi-Asaba and Benin Formation as outcropping series is well presented in Table 2 .

Anambra State is underlain by the Upper Maastrichtian to Danian Nsukka Formation outcropping in the eastern parts of the State around Ufuma and is successively overlain by the Paleocene Imo Formation, LowerMiddle Eocene Ameki Group, Upper Eocene to Oligocene Ogwashi-Asaba Formation, Miocene Benin Formation and alluvium in the western parts. The Ajali Formation also outcrops in the southeastern boundary of the Anambra basin. The Ameki Group dominates the geology of the state and the group is differentiated into the Ameki Formation, Nanka Formation and the Nsugbe Formation (Nwajide, 1979; Nwajide, 1980; Nwajide, 2013). Nwajide (2013) described the Ameki Formation and the Nanka Formation as being indistinguishable because of similarity in gross sedimentary and depositional characteristics and the closeness of the two type localities. The two formations were described to be composed of calcareous clays and silts with thin shelly limestone and fossiliferous heteroliths. Some prominent lignite outcrops are shown in Fig. 2.

Table 1. Stratigraphic succession in the Anambra and Niger Delta Basins

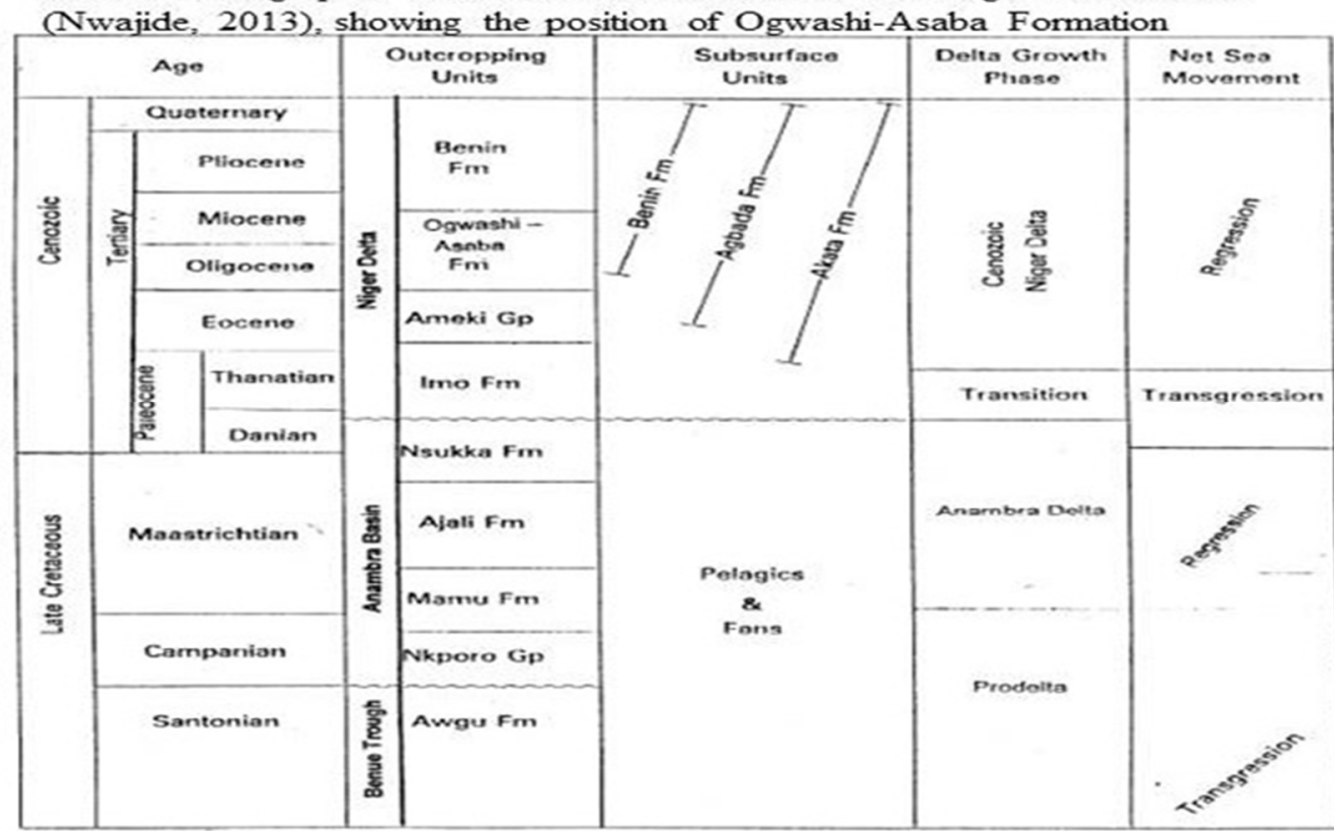

Table 2. Outcropping units of the Cenozoic Niger Delta (Nwajide, 2013)

\begin{tabular}{|c|c|c|c|}
\hline Age span & \multicolumn{2}{|c|}{ Lithostrat. Unit } & Characteristics \\
\hline $\begin{array}{l}\text { Oligocene - } \\
\text { Present }\end{array}$ & \multicolumn{2}{|c|}{ Benin Fm } & $\begin{array}{l}\text { Known also as the coastal plains sands; cross-bedded, coarse } \\
\text { pebbly continent sand, with clay lenses and lignites; has } \\
\text { marine shale breaks with foraminifera, ostracods and molluscs }\end{array}$ \\
\hline $\begin{array}{l}\text { Oligicene - } \\
\text { Miocene }\end{array}$ & \multicolumn{2}{|c|}{ Ogwashi- Asaba Fm } & Clays, silts and sand with thin lignite seams. \\
\hline \multirow[t]{2}{*}{$\begin{array}{l}\text { Eocene-Early } \\
\text { Oligocene }\end{array}$} & \multirow[t]{2}{*}{ Ameki Group } & Nsugbe Fm & \multirow{2}{*}{$\begin{array}{l}\text { Mainly sands with some conglomerate bands } \\
\text { Calcareous clays and silts with shelly limestone, rich in } \\
\text { foraminifera, mainly sands, minor silts and clay intercalations }\end{array}$} \\
\hline & & $\begin{array}{l}\text { Nanka Fm } \\
\text { Ameki Fm }\end{array}$ & \\
\hline $\begin{array}{c}\text { Paleocene - Early } \\
\text { Eocene }\end{array}$ & \multicolumn{2}{|c|}{ Imo Formation } & $\begin{array}{l}\text { Blue - grey shales with sand lenses, marls and fossiliferous } \\
\text { limestones, sandstone members - Ebenebe, Umuna and } \\
\text { Igbaku Sandstones, shales with foraminifera and ostracods }\end{array}$ \\
\hline
\end{tabular}




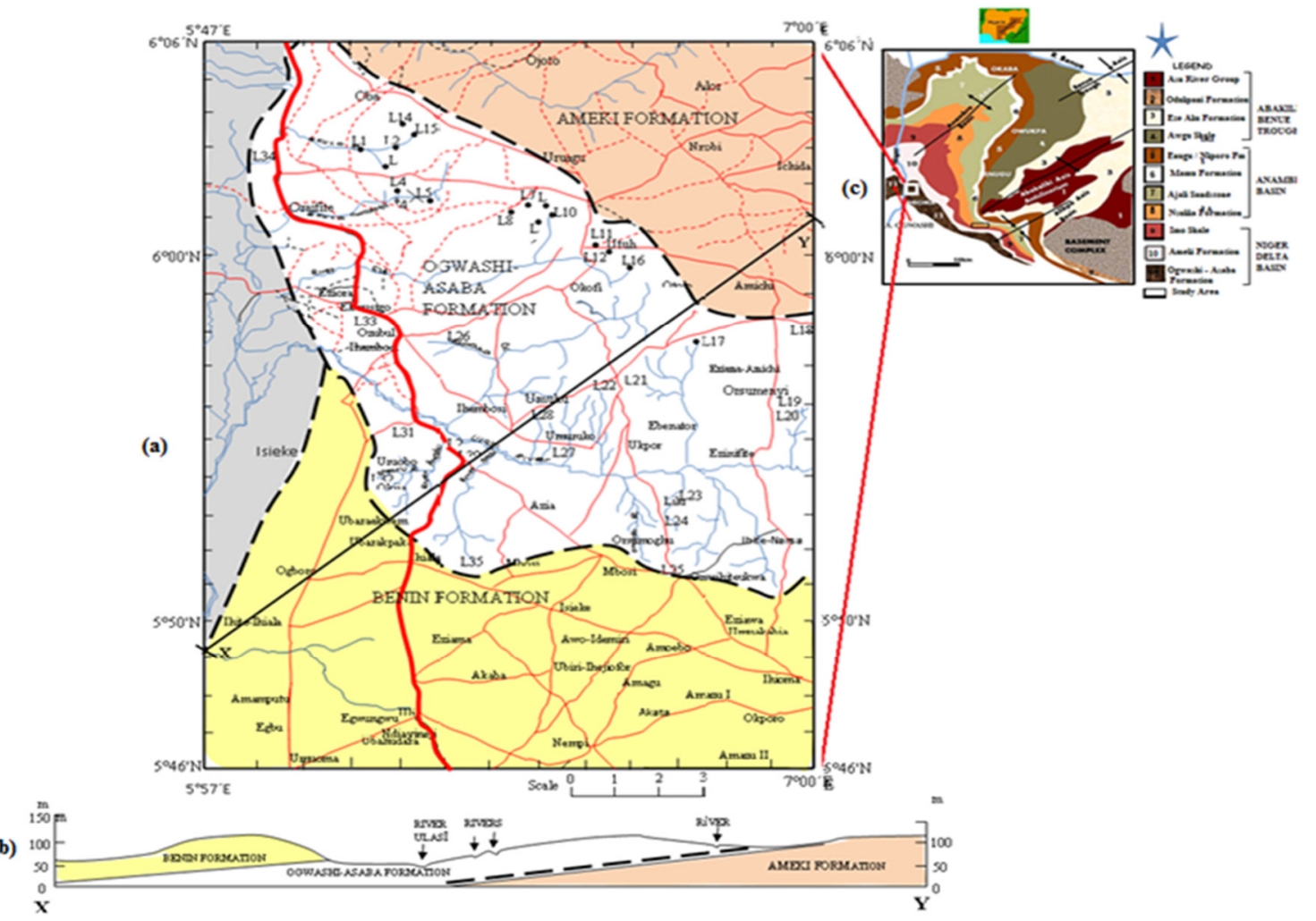

Fig. la: Geologic map of the study area (1b): Geologic cross-section through the line X - Y

(lc) : Geologic map of South-Eastern Nigeria.
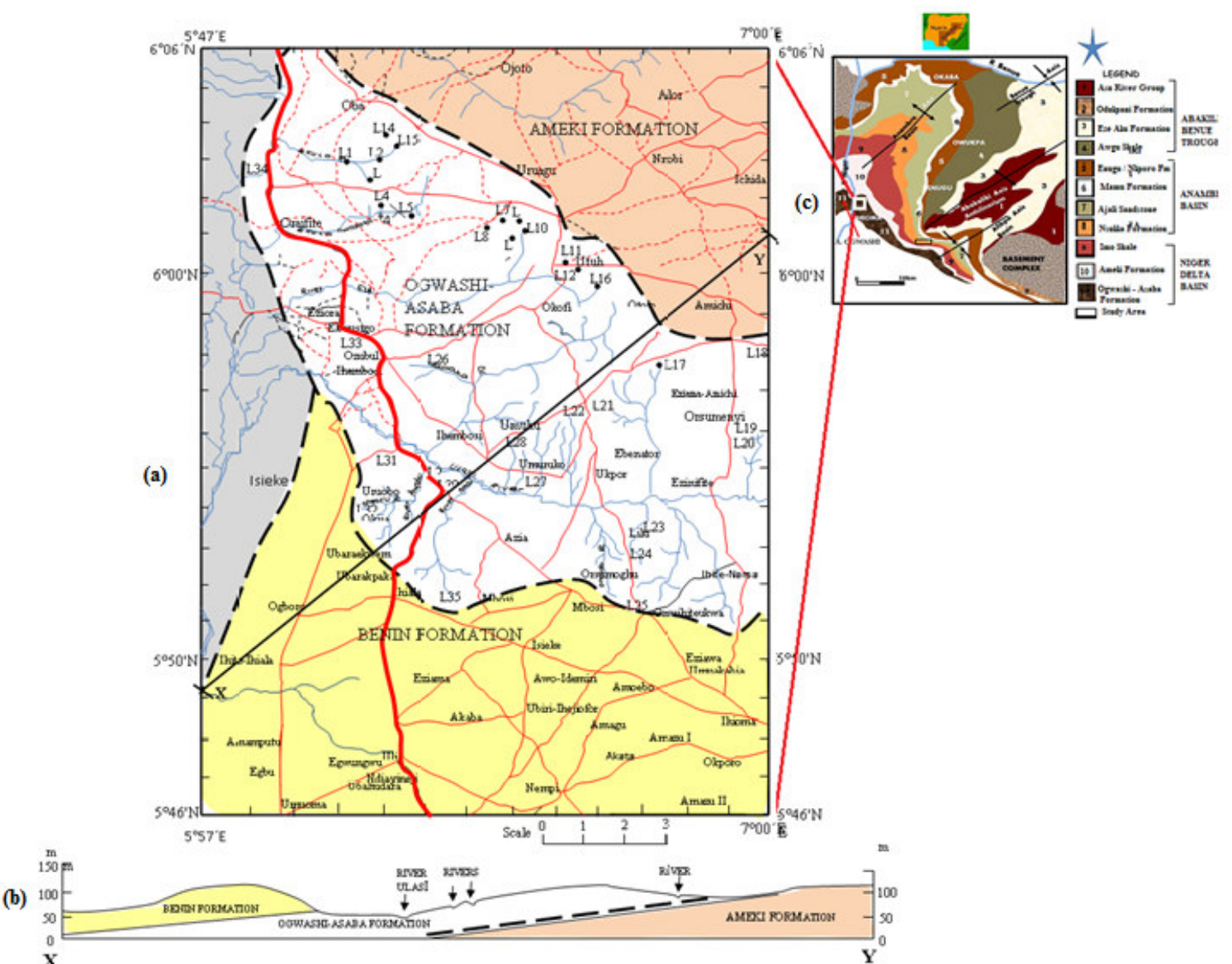

Fig. la: Geologic map of the study area (lb): Geologic cross-section through the line X - Y (lc) : Geologic map of South-Eastern Nigeria. 


\begin{tabular}{|l|l|c|c|c|}
\hline \multicolumn{5}{|c|}{ Table 3: Outcrop locations and their various coordinates } \\
\hline S/N & Outcrop locations & Longitude & Latitude & $\begin{array}{c}\text { Elevation } \\
(\mathrm{m})\end{array}$ \\
\hline 1 & Enem stream & $06^{\circ} 0112^{1} \mathrm{~N}$ & $006^{\circ} 5136^{1} \mathrm{E}$ & 90 \\
\hline 2 & Ejighioku Amakom Oraifite & $06^{\circ} 01613^{1} \mathrm{~N}$ & $006^{\circ} 51615^{1} \mathrm{E}$ & 110 \\
\hline 3 & Oruru Awor Ifite Oraifite & $06^{\circ} 01252^{1} \mathrm{~N}$ & $006^{\circ} 51804^{1} \mathrm{E}$ & 106 \\
\hline 4 & Mkpazi Akamiri Umudim Nnewi & $06^{\circ} 00435^{1} \mathrm{~N}$ & $006^{\circ} 5357^{1} \mathrm{E}$ & 91 \\
\hline 5 & Amaiyi Okpunoeze Umudim Nnewi & $06^{\circ} 00917^{1} \mathrm{~N}$ & $006^{\circ} 53796^{1} \mathrm{E}$ & 129 \\
\hline 6 & Obiakoloma & $06^{\circ} 00914^{1} \mathrm{~N}$ & $006^{\circ} 53726^{1} \mathrm{E}$ & 129 \\
\hline 7 & Ekulo Uruezeakwa Oba & $06^{\circ} 02585^{1} \mathrm{~N}$ & $006^{\circ} 50763^{1} \mathrm{E}$ & 66 \\
\hline 8 & Eze Ezumeri stream Oraifite & $06^{\circ} 00762^{1} \mathrm{~N}$ & $006^{\circ} 53954^{1} \mathrm{E}$ & 120 \\
\hline 9 & Ekulo Umuezegbogu & $06^{\circ} 02880^{1} \mathrm{~N}$ & $006^{\circ} 51557^{1} \mathrm{E}$ & 112 \\
\hline 10 & Akpuchara & $06^{\circ} 02860^{1} \mathrm{~N}$ & $006^{\circ} 51408^{1} \mathrm{E}$ & 103 \\
\hline 11 & Eze stream Okpunoeze Uruagu Nnewi & $06^{\circ} 00847^{1} \mathrm{~N}$ & $006^{\circ} 54055^{1} \mathrm{E}$ & 132 \\
\hline 13 & Oduga stream Otolo Nnewi & $06^{\circ} 0112^{1} \mathrm{~N}$ & $006^{\circ} 5136^{1} \mathrm{E}$ & 80 \\
\hline 14 & Ofalla River Utuh & $06^{\circ} 57222^{1} \mathrm{~N}$ & $006^{\circ} 57773^{1} \mathrm{E}$ & 63 \\
\hline 15 & Nneolu Okija & $05^{\circ} 53394^{1} \mathrm{~N}$ & $006^{\circ} 50889^{1} \mathrm{E}$ & 70 \\
\hline 16 & Anthill & $06^{\circ} 59951^{1} \mathrm{~N}$ & $006^{\circ} 55218^{1} \mathrm{E}$ & 99 \\
\hline 17 & Toll gate Ogbunike & $05^{\circ} 55969^{1} \mathrm{~N}$ & $006^{\circ} 59219^{1} \mathrm{E}$ & 92 \\
\hline
\end{tabular}

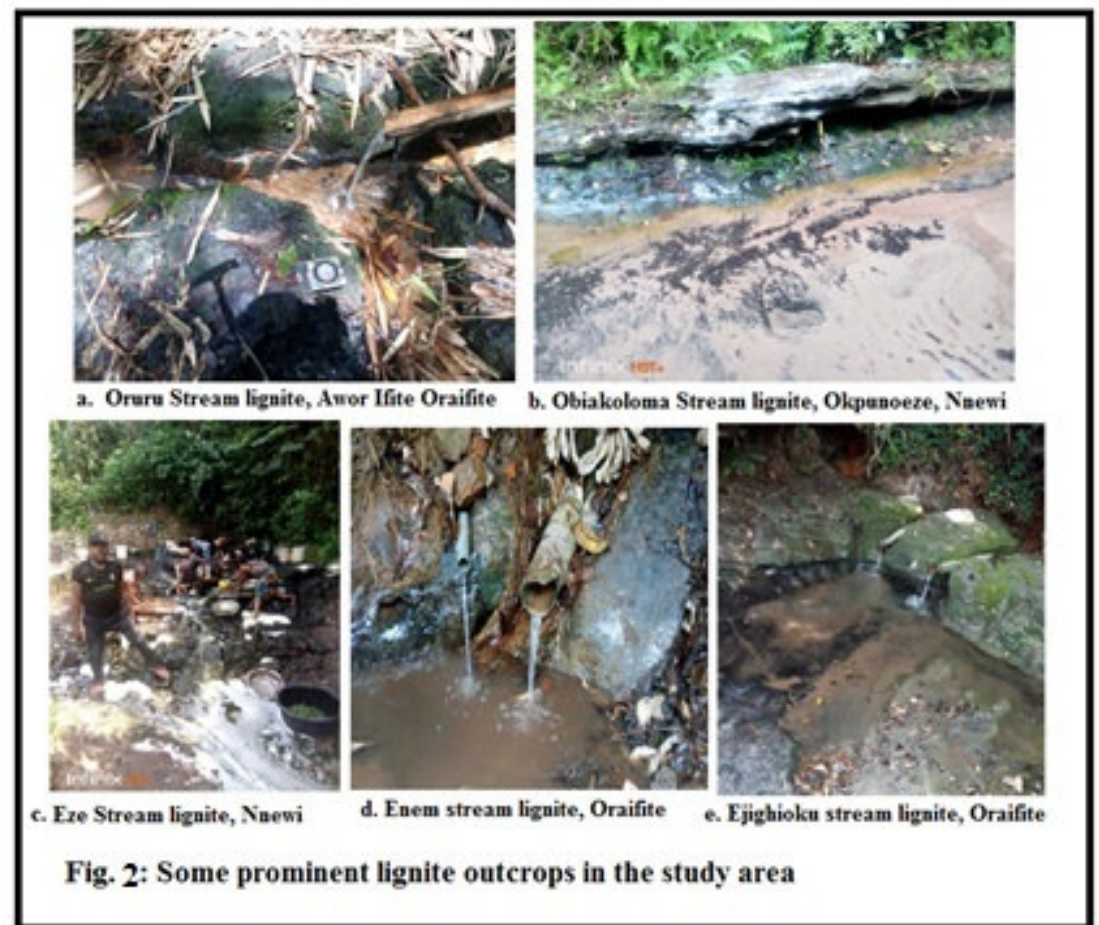

\subsubsection{Methodology}

The methodology involves both field and laboratory studies. Several outcrops (Fig. 1, Table 3) were systematically logged and described. About twelve fresh lignite samples (1 kg each) were collected from all the identified beds following the procedures discussed by Schopf (1960) and guidelines of Swanson and Huffman (1976). Samples with obvious clay partings or impurities were excluded. Samples were pulverized to about $1.3 \mathrm{~cm}$ sizes and packed in plastic bags to prevent loss of moisture on transit and eliminate possible trace metal contamination from cans or cloth bags.

Laboratory analyses were carried out at the National Geosciences Research Laboratory, Kaduna. Laboratory analysis did include proximate, ultimate analysis and bomb calorimetry of the brown coal (lignite) samples. The proximate analysis releases the following products; moisture content, ash content, volatile matter, fixed carbon and calorific values when the brown coal (lignite) is heated under specified conditions. The ultimate analysis is the percentage of hydrogen, oxygen, sulfur and nitrogen contained in the lignite under specified laboratory conditions.

Each sample of about $1 \mathrm{~kg}$ of brown coal (lignite) were grounded and passed through a 210 micron sieve. 
The powdered brown coal is then used for proximate and ultimate analysis following the procedures used by Afonja (1996).

\section{A. Proximate Analysis}

The proximate parameters determined in this study include moisture content, volatile matter, ash content, fixed carbon and calorific values.

(i) Moisture Content Determination (M): This is a very important property of coals. In order to determine the moisture content, $1 \mathrm{gm}$ of coal sample is weighed in a silica crucible and dried in a minimum free space oven at temperature of $110{ }^{\circ} \mathrm{C}$ for about four hour in nitrogen atmosphere. The crucible together with the sample is then removed; cooled in desiccators for about 15 minutes and then weighed. A repeat of this process is done until a consistent weight of the coal sample is recorded. The moisture content is the difference between the original weight of the coal sample and the weight of the dry coal sample which is usually noted in percentages. The percentage of the weight loss is regarded as the moisture content.

Moisture $(\%)=$ loss in weight due to removal of moisture / weight of coal sample taken $\mathrm{x} 100$

This is expressed in the following equation

$$
\mathrm{MC} \%=(\mathrm{Y}-\mathrm{Z}) /(\mathrm{Y}-\mathrm{X}) * 100
$$

Where $\mathrm{X}=$ weight of empty crucible

$\mathrm{Y}=$ weight of crucible + weight of coal sample before heating, $(\mathrm{gm})$

$\mathrm{Z}=$ weight of crucible + weight of coal sample after heating, $(\mathrm{gm})$

$\mathrm{Y}-\mathrm{X}=$ weight of coal sample, $(\mathrm{gm})$

$\mathrm{Y}-\mathrm{Z}=$ weight of moisture, $(\mathrm{gm})$

\section{(ii) Ash Content Determination:}

The ash content refers to the non-combustible matter that remains after water has been expelled during combustion. In order to determine the ash content, $1 \mathrm{gm}$ of brown coal sample is weighed into a crucible incinerated in a special furnace at a temperature of about $450{ }^{\circ} \mathrm{C}$ for about 30 minutes. The temperature of the furnace is then increased to about $850{ }^{\circ} \mathrm{C}$ and heated for another one hour. The crucible is afterwards removed; placed in desiccators and weighed. The ash content is the difference between the initial weight and the final weight. The ash content is the residue on percentage basis.

$$
\text { Ash }(\%)=(\mathrm{Z}-\mathrm{X} / \mathrm{Y}-\mathrm{X}) * 100
$$

Where $\mathrm{X}=$ weight of the empty crucible, $(\mathrm{gm})$

$\mathrm{Y}=$ weight of coal sample + weight crucible $(\mathrm{gm})$ before heating

$\mathrm{Z}=$ weight of coal sample + weight of crucible $(\mathrm{gm})$ after heating

\section{(iii) Determination of Volatile Matter:}

The volatile matter refers to the component of coal (except moisture) that is expelled at temperature in the absence of air and it consists of mixtures of short to long chain hydrocarbons, aromatic hydrocarbons and some sulfur. Volatile matter is determined by heating about $1 \mathrm{gm}$ of crushed coal sample in a minimum air at $900{ }^{\circ} \mathrm{C}$ for seven minutes. The sample heated is then cooled in a desiccator and weighed. Repeat the process until a consistent weight of the sample is recorded. The loss in weight (\%) is reported as volatile matter.

Volatile matter $(\%)=($ loss in weight due to removal of volatile matter/wt of coal sample used $) \times 100$. Volatile matter is expressed as follows;

$$
\mathrm{VM}(\%)=(\mathrm{Y}-\mathrm{Z}) /(\mathrm{Y}-\mathrm{X}) * 100-\mathrm{M} \%
$$

Where $\mathrm{X}=$ weight of empty crucible, $(\mathrm{gm})$

$\mathrm{Y}=$ weight of crucible + weight of coal sample before heating, $(\mathrm{gm})$

$\mathrm{Z}=$ weight of crucible + weight of coal sample after heating, $(\mathrm{gm})$

$\mathrm{Y}-\mathrm{X}=$ weight of coal sample, $(\mathrm{gm})$

$\mathrm{Y}-\mathrm{Z}=$ weight of volatile matter + moisture, $(\mathrm{gm})$

\section{(iv) Fixed Carbon Determination}

The fixed carbon is the carbon found in the material when volatile matter has been driven off. To determine the percentages of fixed carbon, $1 \mathrm{gm}$ sample of brown coal is ground to pass a $0.2 \mathrm{~mm}$ in a current of oxygen. The carbon dioxide and water formed were absorbed by soda asbestos and magnesium per chlorate respectively. This level of carbon content is then determined gravimetrically. Fixed carbon is also determined on air dry basis by subtracting the sum of the other parameters from 100 and is expressed thus;

Where

$$
\mathrm{FC}=100-(\mathrm{M}+\mathrm{VM}+\mathrm{A})
$$

$\mathrm{M}=$ Moisture Content $(\%)$

$\mathrm{VM}=$ Volatile Matter $(\%)$

$\mathrm{A}=$ Ash content $(\%)$ 


\section{(v) Calorific Values}

B. Ultimate Analysis

The ultimate parameters determined in this study include carbon, hydrogen, oxygen and sulfur.

(i) Carbon and Hydrogen Determination: A $1 \mathrm{gm}$ sample taken from the coal ground to pass a $0.2 \mathrm{~mm}$ test sieve was burnt in a three-stage Lieberg furnace in a current of oxygen. The carbon dioxide and water formed were absorbed by soda asbestos and magnesium per chlorate respectively, and determined gravimetrically to ascertain the level of carbon and hydrogen contents. The trend is that the higher the fixed carbon greater the calorific value and hence the better the quality of coal.

(ii) Oxygen Determination: The finely crushed coal was pyrolized at $1200^{\circ} \mathrm{C}$ in a current of nitrogen and the resultant gases passed over activated carbon at $200^{\circ} \mathrm{C}$. This converts the oxygenated products into $\mathrm{CO}$ which was then oxidized to $\mathrm{CO}_{2}$ by reacting with $\mathrm{O}_{2}$. The oxygen content was then determined using classical method.

(iii) Sulphur Determination: The sulphur content was determined by mixing a $1 \mathrm{gm}$ sample of coal of $0.2 \mathrm{~mm}$ particle size with Eschka mixture and heated until all the sulphur was converted to sulphate. The resultant sulphate solution was then extracted and determined gravimetrically by precipitation with barium chloride. Eschka mixture refers to a mixture of either $\mathrm{K}_{2} \mathrm{CO}_{3}$ or $\mathrm{Na}_{2} \mathrm{CO}_{3}$ and magnesia but in this study $\mathrm{Na}_{2} \mathrm{CO}_{3}$ (sodium carbonate) was used. The nature of the sulphur analyzed in the coal was determined by boiling a $5 \mathrm{gm}$ sample of coal with dilute hydrochloric acid to bring the sulphate sulphur and non-pyritic iron into solution and filtered. The filtrate was then made alkaline to precipitate the non-pyritic iron which was then removed by filtration. The sulphate sulphur was precipitated from the filtrate as barium sulphate and determined gravimetrically. The difference between the total sulphur and sum of the pyritic sulphur and sulphate sulphur was computed as the organic sulphur. This is illustrated in the formula: Sorg = Stotal (Ssulphate + Spyrite).

\subsubsection{RESULTS AND DISCUSSION}

\section{(a) Proximate Analysis}

The results of proximate analysis for moisture, volatile matter, fixed carbon, and ash content are given in Table 4 and Fig. 3

Table 4: Descriptive Statistics of proximate Analysis of brown coal (Lignites) from Ogwashi-Asaba Formation in Anambra State

\begin{tabular}{|c|c|c|c|c|c|c|c|c|c|c|c|c|c|c|c|}
\hline \multirow{2}{*}{$\begin{array}{l}\% \text { Proximate } \\
\text { Analysis }\end{array}$} & \multicolumn{4}{|l|}{ Nnewi } & \multirow{2}{*}{$\begin{array}{l}\text { Ogbunike } \\
\\
\end{array}$} & \multicolumn{2}{|l|}{ Oba } & \multirow{2}{*}{ 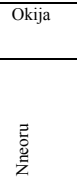 } & \multicolumn{3}{|l|}{ Oraifite } & \multicolumn{2}{|l|}{ Utuh } & \multirow[b]{2}{*}{ 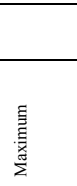 } & \multirow[b]{2}{*}{ 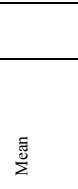 } \\
\hline & 蛋 & $\begin{array}{l}\text { 㺃 } \\
\text { 胥 }\end{array}$ & 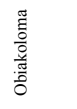 & 胥 & & $\frac{}{\bar{y}}$ & 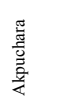 & & $\begin{array}{l}\text { 吾 } \\
\text { 离 } \\
\text { 咅 }\end{array}$ & 駡 & 竐 & 遌 & 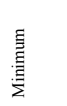 & & \\
\hline $\begin{array}{l}\begin{array}{l}\text { Moisture } \\
\text { content }\end{array} \\
\end{array}$ & 7.30 & 11.40 & 7.20 & 26.80 & 2.40 & 17.30 & 16.50 & 34.50 & 12.10 & 30.70 & 20.20 & 43 & 2.40 & 43 & 19.14 \\
\hline Ash content & 27.80 & 63.40 & 36.60 & 8.20 & 83.50 & 6.60 & 31.30 & 12.60 & 70.75 & 12.40 & 9.40 & 22 & 6.60 & 70.75 & 32.21 \\
\hline $\begin{array}{l}\begin{array}{l}\text { Volatile } \\
\text { content }\end{array} \\
\end{array}$ & 33.60 & 15.30 & 33.04 & 33.05 & 2.44 & 38.40 & 27.55 & 28.05 & 15.55 & 33.63 & 39.92 & 23 & 2.44 & 39.92 & 26.96 \\
\hline Fixed carbon & 29.20 & 9.83 & 23.08 & 31.65 & 1.51 & 37.50 & 24.35 & 24.40 & 1.60 & 23.21 & 30.40 & 12 & 1.51 & 37.50 & 20.72 \\
\hline Sulfur & 0.10 & 0.07 & 0.08 & 0.20 & 0.51 & 0.20 & 0.30 & 0.15 & 0.04 & 0.06 & 0.08 & 0.11 & 0.04 & 0.51 & 0.16 \\
\hline $\begin{array}{l}\text { Calorific value } \\
\mathrm{Kcal} / \mathrm{kg} \\
\end{array}$ & 366 & 1281.55 & 3210.74 & 3887.74 & 435.10 & 4583.79 & 3023.46 & 3082.92 & 582.23 & 3188.76 & 4035.64 & 2031.22 & 435.10 & 4583.79 & 2806.607 \\
\hline $\begin{array}{l}\text { Calorific value } \\
\mathrm{MJ} / \mathrm{kg}\end{array}$ & 15.33 & 5.54 & 13.44 & 13.44 & 1.82 & $\begin{array}{l}19.19 \\
\end{array}$ & 12.66 & 12.91 & 2.44 & 13.35 & 16.90 & 8.50 & 1.82 & $\begin{array}{l}19.19 \\
\end{array}$ & 11.84 \\
\hline
\end{tabular}

(i) Moisture Content (MC)

All coals are mined wet therefore moisture content is an important factor of coal. The total moisture content is important in assessing and controlling the commercial processing of lignite. The groundwater and other extraneous moisture known as adventitious moisture is readily evaporated while the moisture held within the coal itself is inherent moisture that is analysed quantitatively. The inherent moisture content decreases as the coalification process progresses. Generally, the moisture content of coals ranges from $5 \%$ to nearly $70 \%$ which is an undesirable constituent as it reduces the heating value and adds weight to the transportation cost. In this study, the increased contents of this physically and chemically adsorbed water are characteristic of lower-rank coals, while the decreased values of this parameter are typical of higher-rank coals (Vassilev et al, 1996; Jauro et al, 2008). The moisture content value of the brown coal samples studied ranges between 2.40 to $43.00 \mathrm{wt}$. \% and arithmetic mean of 19.14 wt. \% indicating the low rank coal status of lignite, which is gradually tending towards sub-bituminous coal (Table 4). The brown coal samples with the highest moisture content is from Ofala stream followed by that from Nneoru stream Okija (32.80\%), Enem stream in Oraifite (30.70\%), Eze stream in Nnewi $(26.80 \%)$ and the least is from Ose - Ogbunike (2.40 wt \%) (Fig. 3).

Since the coal samples have an average of $19.14 \mathrm{wt}$. \% moisture, it is considered to be too high for a coking coal. The high moisture content is an indication that the coal is of low rank, possibly the rank of sub-bituminous 
grade. It can also be inferred that the coal has not sufficiently experience deep burial to warrant enough transformation at the phase of catagenesis during which an appreciable part of the moisture would have been lost. The coal therefore may not be suitable for high-energy generation or the blast furnace due to its high moisture content.

Table 5: Variation of selected coal properties with coal rank (http://www.ems.psu.edu/ radovic/Chapter7.pdf.)

\begin{tabular}{|c|c|c|c|c|}
\hline \multirow[b]{2}{*}{ Rank: } & \multicolumn{2}{|c|}{ 口-_Low Rank-_-_-_-_-_ } & \multicolumn{2}{|c|}{ 口--_High Rank---_--- } \\
\hline & Lignite & Sub-bituminous & Bituminous & Anthracite \\
\hline Age: & $-\ldots$ & -Incre & $-\ldots$ & 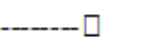 \\
\hline \% Carbon: & $65-72$ & $72-76$ & $76-90$ & 90-95 \\
\hline \% Hydrogen: & $\sim 5-\cdots$ & -decreas & - & $\sim 2$ \\
\hline \% Nitrogen: & 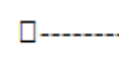 & $\sim 1-2$ & - & - \\
\hline \% Oxygen: & $\sim 30$ & --decrea & - & $--\sim 1$ \\
\hline \% Sulphur: & $\sim 0$ & -increase--_-_- $\sim 4$ - & - decreases----. & $--\sim 0$ \\
\hline \% Water: & $70-30$ & $30-10$ & $10-5$ & $\sim 5$ \\
\hline $\begin{array}{l}\text { Heating value } \\
\text { (BTU/lb) : }\end{array}$ & $\sim 7000$ & $\sim 10,000$ & $12,000-15,000$ & $\sim 15,000$ \\
\hline
\end{tabular}

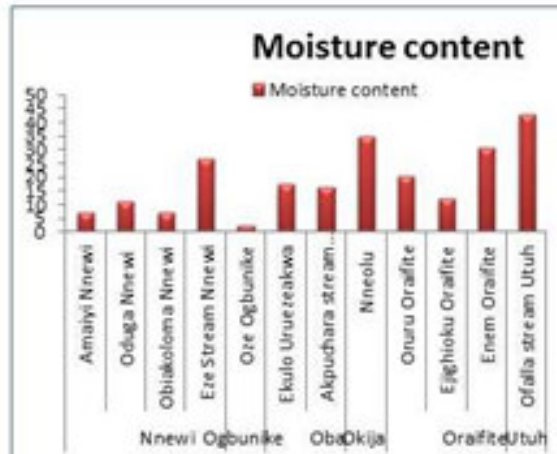

Fig. 3. Percent compositions of air dry moisture present in brown coal

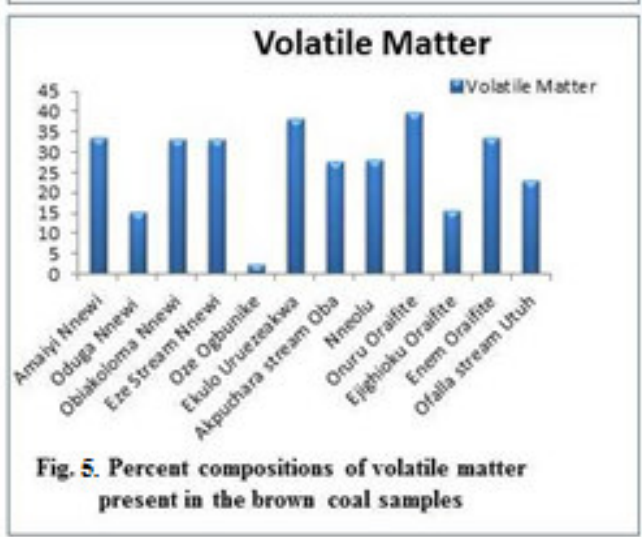

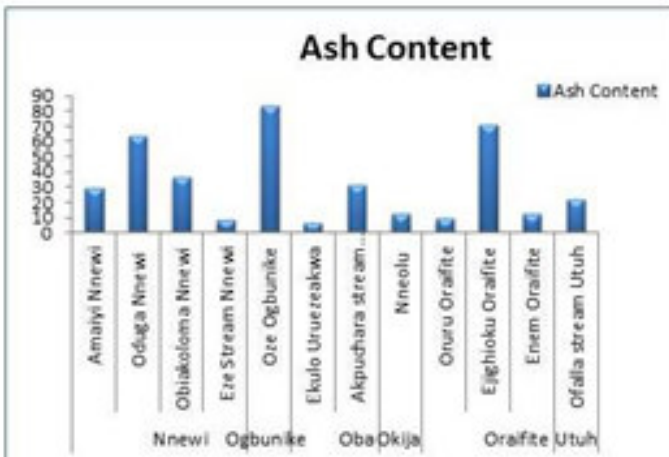

Fig.4. Percent compositions of ash content preseat in browa coal samples

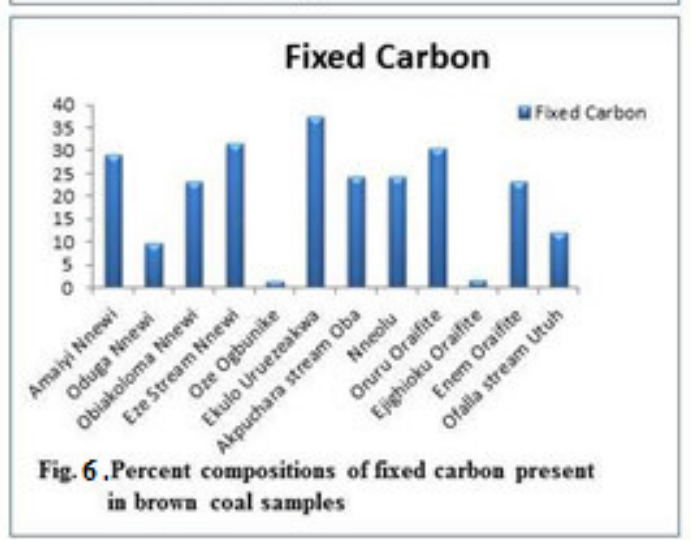

(i) Ash Content (AC)

The ash content of coal is the non-combustible residue left after the coal is burnt representing the bulk mineral matter after carbon, oxygen, sulphur and water are driven off during combustion indicating the quality of coal. The ash content suggests the quality of the coal. The ash contents (dry base) of the analyzed brown coal samples vary from 6.60 to $70.75 \mathrm{wt} \%$ and arithmetic mean of $32.21 \mathrm{wt} \%$ (Fig. 4). Brown coals from Ekulo stream in Oba is characterized with lowest ash content of $6.60 \%$, compared to other brown coal samples in this study (Table. 4). However, the ash content of brown coal from Oze-Ogbunike (83.50\%) and Ejighioku stream Oraifite $(70.75 \%)$ are observed to be very high. The lower amount of ash in coal is extremely important for coal's purity and high price. That is why coal gradation is done based on ash content. In case of coal grading, Ash $<8 \%$ for Superior coal, Ash $\geq 8$ but $<12$ for Good coal, Ash $\geq 12$ but $<16$ for Fair coal and Ash $>16 \%$ for poor coal [45]. The 
concentration value of the ash content shows that $30 \%$ of the samples are good, the rest are poor with one superior from Ekulo Uruezeakwa Oba (Table 5b)

Previous study has shown that ash content affects the composition, volume and performance of blast furnace coke negatively (Berkowitz, 1979). The high ash yield is normally marked by the relatively abundant supply of detrital materials in swamp, wherein; the authigenic minerals dominate mostly with low-ash $(8-10 \%)$ coals, whereas the proportion of detrital minerals increases (Finkelman, 1988). This observation is consistent with the assertion by Sahni et. al. (2006) that some low-ash $(<10 \%)$ coals contain mainly authigenic and biogenic inorganic matter, whereas those with higher ash yield ( $>10 \%)$ show simultaneous enrichment in detrital and authigenic inorganics. In this study, most of the samples have high ash yield indicating enrichment in detrital and authigenic inorganics except for brown coals from Ekulo stream and Eze stream with ash value of 6.60 and 8.20 respectively. Most of the brown coals in this study have limited applications because of its being incombustible, higher cost of handling and processing of the ash ${ }^{[36]}$. Brown coals from Ekulo stream and Eze stream has lower ash values and are cheaper to process and handle. High ash content in brown coals is known to give rise to a high slag volume and low blast furnace efficiency. It also results in high coke rate, which is a consequence of accelerated oxidation of coke by carbon dioxide and oxygen due to the catalytic activities of the metallic oxides in the ash. The high ash content is also an indication of low degree of coalification. According to Afonja (1976) coking coal with ash content up to $20 \%$ is being used for smelting iron in some parts of the world.

Table 5b: Ash content analysed and their grading

\begin{tabular}{|c|c|c|c|c|c|c|c|c|c|c|c|}
\hline & \multicolumn{4}{|c|}{ Nnewi } & Ogbunike & \multicolumn{2}{c|}{ Oba } & \multicolumn{2}{c|}{ Okija } & \multicolumn{2}{c|}{ Oraifite } \\
\hline $\begin{array}{c}\text { \% Proximate } \\
\text { Analysis }\end{array}$ & $\begin{array}{l}\text { Amaiyi } \\
\text { Stream }\end{array}$ & $\begin{array}{l}\text { Oduga } \\
\text { Stream }\end{array}$ & $\begin{array}{l}\text { Obiakolo } \\
\text {-ma stream }\end{array}$ & Eze Stream & $\begin{array}{l}\text { Oze - Ogbu } \\
\text {-nike }\end{array}$ & $\begin{array}{l}\text { Ekulo } \\
\text { Stream }\end{array}$ & $\begin{array}{l}\text { Akpuchara } \\
\text { Stream }\end{array}$ & $\begin{array}{l}\text { Nneolu } \\
\text { Stream }\end{array}$ & $\begin{array}{l}\text { Oruru } \\
\text { Stream }\end{array}$ & $\begin{array}{l}\text { Ejighioku } \\
\text { Stream }\end{array}$ & $\begin{array}{l}\text { Enem } \\
\text { Stream }\end{array}$ \\
\hline Coal Grade & Poor coal & Poor coal & Poor Coal & Good Coal & Poor Coal & $\begin{array}{l}\text { Superior } \\
\text { Coal }\end{array}$ & Poor Coal & Fair Coal & Good Coal & Poor Coal & $\begin{array}{l}\text { Good } \\
\text { Coal }\end{array}$ \\
\hline Ash Content & 29.80 & 63.40 & 56.60 & 8.20 & 83.50 & 6.60 & 31.30 & 12.60 & 9.40 & 70.75 & 12.40 \\
\hline
\end{tabular}

(i) Volatile Matter (VM)

Volatile matter is usually measured in the absence of moisture and ash and ranges from $2 \%$ to about $50 \%$. In domestic stoves and furnaces or in small industrial appliances the coals that contain large amounts of volatile matter are easy to ignite it burns quickly and often burn with a long, smoky flame. According to Stach et al (1982), increased VM content is more characteristic of low-rank coals, while the decreased values are generally typical of higher-rank coals. The high VM yield is also indicative for the enrichment in liptinite, hydrocarbons, $\mathrm{CO}, \mathrm{CO}_{2}$, and chemically combined water, and for the depletion in inertinite (Eskenazy, 1978 ; Berkowitz, 1979). The volatile matter content in the analysed samples ranges between 2.44 to $39.92 \mathrm{wt} \%$, with arithmetic mean of 26.96 wt $\%$ (Table 4, Fig. 5). The results suggest generally low volatile matter content as shown in Fig. 5. The average value of $26.96 \mathrm{wt} \%$ suggests a low volatile matter content which is an indication that the coal is tending towards sub-bituminous coal. Afonja (1976) suggested the volatile matter content of coking coals to range between 20 and 32 percent. This therefore suggests the brown coals in the study area as having appreciable coking coal characteristics.

(ii) Fixed Carbon (FC)

The fixed carbon content of the coal is the carbon found in the material which is left after volatile materials are driven off. This differs from the ultimate carbon content of the coal because some carbon is lost in hydrocarbons with the volatiles. The fixed carbon value is used in determining the efficiency of lignite/coal burning equipment. It is also a measure of the solid combustible material that remains after the volatile matter in coal/lignite has been removed. Fixed carbon is used as an estimate of the amount of coke that will be yielded from a sample of coal. The fixed carbon content of the samples in the study area varies between 1.51 and $37.50 \mathrm{wt} \%$ with arithmetic mean of $20.72 \mathrm{wt} \%$. Fig. 6 shows the percent fixed carbon in each of the coal reserves studied. The highest fixed carbon content of $37.50 \%$ was observed in brown coal samples from Ekulo stream, followed by Oruru stream $(30.40 \%)$, Amaiyi stream (29.20\%) and Nneoru stream (24.40\%) and at Oze-Ogbunike (1.51\%). The average carbon content of the brown coal in this study is $20.72 \mathrm{wt} \%$, which may be considered low, which an indication of the relatively young nature of the coal, probably the lowest rank of coal - lignite. The percentage fixed carbon and ash contents of the brown coal in this study compared with other Nigerian coals in decreasing order: Enugu coal $>$ Benue coal $>$ Delta coal $>$ Anambra coal (Table 6). The percentage moisture and volatile matter contents in the coal samples decreased as follows: Delta coal $>$ Benue coal $>$ Enugu coal $>$ Anambra coal. Proximate analysis of the coal samples showed that Enugu and Benue coal deposits fall within the rank of sub-bituminous coal while Delta and Anambra are lignites (Low, 1963).

(iii) Calorific Value

Calorific value is the amount of potential energy that can be converted into actual heating ability. It indicates the 
degree of heat content of the coals. Bomb calorimetry was used to determine the Net Calorific Value (NCV). The observed trend is that the higher the fixed carbon, the greater the calorific value and hence the better the quality of the coal. The brown coal sample from Ekulo stream has the highest NCV of $4583.79 \mathrm{~J} / \mathrm{Kg}(19.19 \mathrm{MJ} / \mathrm{Kg})$ followed by Oruru stream (4035.64 J/Kg / 16.89 MJ/Kg), Eze stream (3887.47 J/Kg, $14.18 \mathrm{MJ} / \mathrm{Kg})$, Nneoru stream (3083.92 $\mathrm{J} / \mathrm{Kg} / 12.91 \mathrm{MJ} / \mathrm{Kg}$ ) and Oze-Ogbunike (1.82 MJ/Kg). Inaner (2005) suggested that lignites with calorific values lower than $10.46 \mathrm{MJ} / \mathrm{kg}$ could be useful as fuel in power plants while those with calorific values higher than 10.46 $\mathrm{MJ} / \mathrm{Kg}$ are more suitable for household and industrial uses. About forty percent of the analyzed samples have values lower than $10.46 \mathrm{MJ} / \mathrm{Kg}$ while the remaining sixty percent have calorific values higher than $10.46 \mathrm{MJ} / \mathrm{Kg}$ (Fig. 7), suggesting the majority of the lignites of Ogwashi-Asaba Formation as being ideal for household and industrial uses.
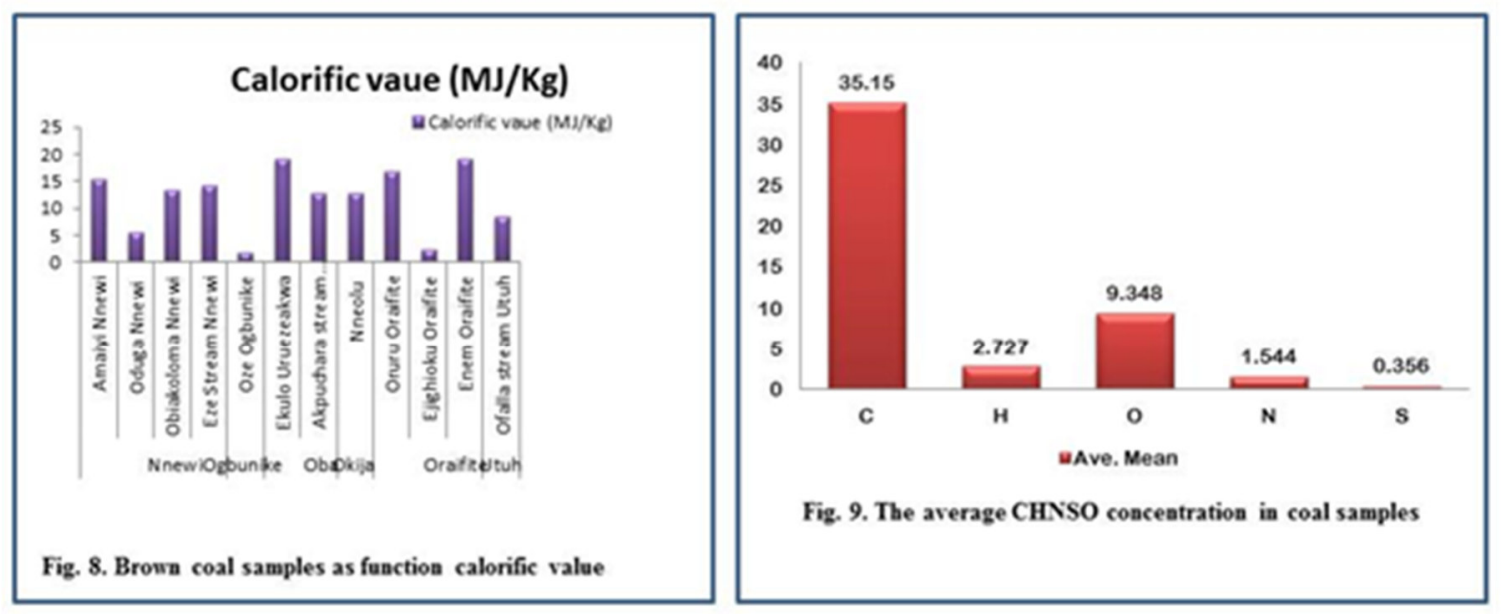

\begin{tabular}{|l|l|l|l|l|}
\hline \multicolumn{5}{|l|}{ Table6. Comparing Proximate Analysis result of the coal samples with other parts of Nigeria } \\
\hline \% proximate Analysis & Enugu coal & Delta coal & Benue coal & Anambra coal \\
\hline Total moisture content (MC) & 23.70 & 35.61 & 26.60 & 19.14 \\
\hline Ash Content (AC) & 14.30 & 12.00 & 13.91 & 32.21 \\
\hline Volatile Matter (VM) & 41.30 & 59.50 & 43.10 & 26.96 \\
\hline Fixed Carbon Content (FCC) & 69.80 & 65.90 & 68.10 & 20.72 \\
\hline
\end{tabular}

Results of analytical parameters evaluated such as Carbon, Hydrogen, Sulfur, Nitrogen and Oxygen are presented in Table 7 and Fig. 8. The results for each element are discussed below in details.

Table 7: Descriptive Statistics of Ultimate Analysis of Brown Coals (Lignites) from Ogwashi-Asaba Formation in Anambra State, Nigeria

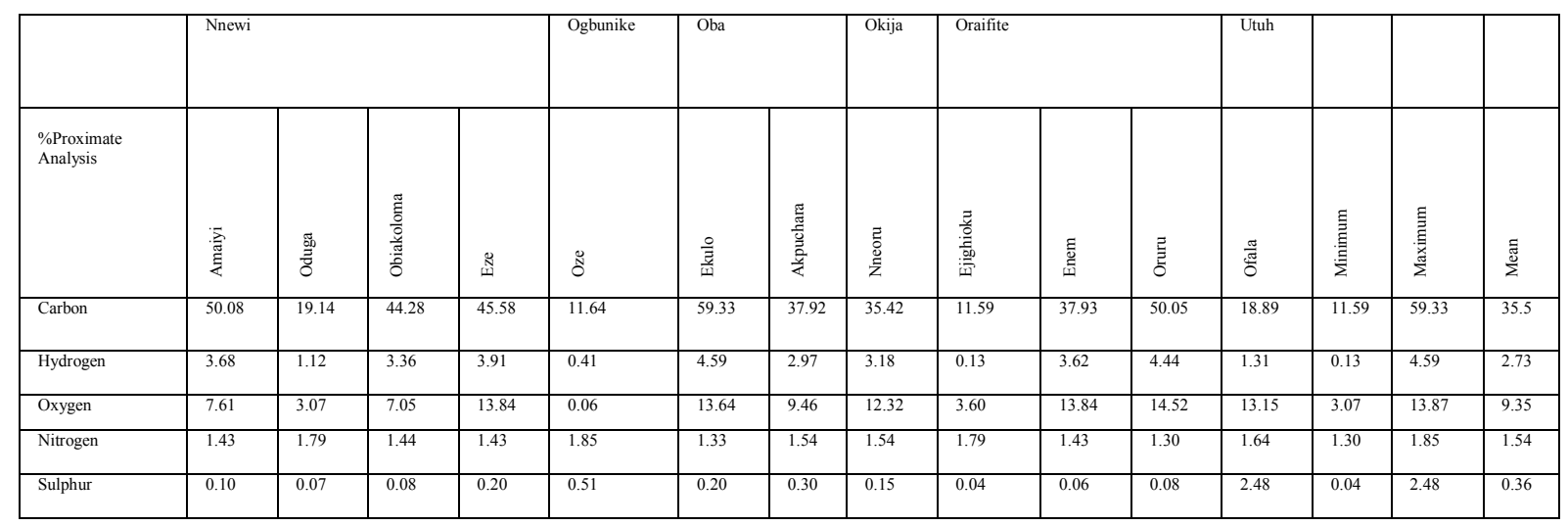

(i)

Carbon (C)

The Carbon content in the collected coal samples from the study area varies from 11.59 to 59.33 wt $\%$ with an arithmetic mean of $35.5 \mathrm{wt} \%$ (Table 6). The high concentrations of $\mathrm{C}$ are normally characteristic of vitrinite macerals (Stach et al, 1982; Li et al, 2010). It is also well known that the C content in coal increases steadily with increasing coal rank therefore, the concentration of the analysed carbon falls within the low rank coal (Stach et al, 
1982; Li et al, 2010) (Table 7). The measurement of C concentration in coal is still the leading and most accurate parameter amongst other chemical characteristics for evaluation of coal rank despite some limitations (Stach et al, 1982; Vassilev et al, 1996; Li et al, 2010). The average carbon content of about $35.5 \%$ in the brown coal is thus considered as being low. This is an indication that the coal in the study area is relatively young and of lignite rank.

\section{(ii) Oxygen (O)}

The Oxygen content in the samples ranges between 0.06 and $13.87 \mathrm{wt} \%$ with an arithmetic mean of $9.35 \mathrm{wt} \%$ (Table 7). The increased content of $\mathrm{O}$ is characteristic of low rank coals, while the decreased concentration is typical of higher-rank coals (Stach et al, 1982; Li et al, 2010). Meanwhile, the increased oxygen concentration in the coal samples is as a result of increased content, hydrated minerals or as a result of advanced coal weathering.

(iii)

Hydrogen (H)

The hydrogen content is found varying from 0.13 to $4.59 \mathrm{wt} \%$ with an arithmetic mean of $2.73 \mathrm{wt} \%$ (Table 7). The increased content of $\mathrm{H}$ is normally more characteristic of low rank coals, while the decreased values are commonly more typical of higher-rank coals Table 6 . The $\mathrm{H}$ concentrations increase with increasing liptinite, alginite, resinite, sporinite, cutinite and degree of bituminization, as well as residual moisture, hydrated minerals, and methane in coals (Nicholls, 1968; Li et al, 2010), as the coalification process progresses; the carbon (rank) increase while the oxygen and hydrogen contents, decreases. This is generally the case in the study area (Fig. 8).

\section{(iv) Sulphur (S)}

The sulphur content in the lignite samples ranges between 0.04 and $2.48 \mathrm{wt} \%$ with an arithmetic mean of $0.36 \%$ (Table 7). High content of sulfur is dominant in lignites, while reduced values are characteristic of higher-rank coals with few exceptions Table 7. High-S coals are known to derive most of their sulfur from reduction of sulphate ions to $\mathrm{H}_{2} \mathrm{~S}$ in sea or brackish water in the coal beds by microbial processes (Calkins) 1994; Dobrogorskii (1981) proposed that the penetration of sea water in the peat bog has been a major source of sulphate ion in the Donbas Basin.

Sulfur in coal is of special interest because of potential air pollution problems. It occurs in coal in three ways. Organic sulfur, $(0.5 \%$ to about $2 \%$ sulphur content) may be a remnant of sulfur in proteins in the original plant material that was converted to coal, or chemically bonded to the coalifying organic matter by bacterial action. Pyritic sulfur $\left(\mathrm{FeS}_{2}\right)$ may range from about $0.5 \%$ to $7 \%$. The pyrite in coal was formed by reactions of iron and sulfur in water in the coal swamp or in water washing through the coal as it accumulated. Sulfate sulfur occurs usually as iron or calcium sulfates. It is a very minor constituent of most coals. The sulfur content in the coal samples studied is very low with an average value of $0.36 \%$. This places the coal at an advantage in this regard both in terms of usage as a fossil fuel and environmental consideration. High sulphur contents is undesirable in steel and coking coal because it promotes the formation of insoluble iron sulphides during iron making causing brittleness of the iron produced.

The brown coal samples in the study area can be used for several purposes such as power generation, fuels and feedstock for chemicals because their sulfur content is low and as such very limited $\mathrm{SO}_{2}$ gases can be released into the atmosphere.

\section{(v) Nitrogen (N)}

The Nitrogen content in the coal samples of the study area ranges between 1.30 to $1.85 \mathrm{wt} \%$ with an arithmetic mean of $1.54 \mathrm{wt} \%$ (Table 6). The increased content of $\mathrm{N}$ is usually observed in higher-rank coals, while the decreased values of this element are more characteristic of lignite (Fig.8). The nitrogen content of brown coals in this study are relatively low $(1.54 \mathrm{wt} \%)$. In terms of usage, the coal can be used as both coking and non-coking coal because it contains less nitrogen and very limited $\mathrm{NO}_{2}$ gases can be released to the environment.

\section{Possible Industrial Benefits of Anambra Brown Coal}

Based on the analyzed properties of the coal, it is not suitable for high-energy generation or the blast furnace due to its high moisture. The coal can however be used as fossils fuels in rail locomotives, steam boat and for electric generation. By-products of lignite combustion are of high economic value. Another by-product, bottom ash, can be used as aggregate in road bases, pavement and cement, as well as good alternative to sand for roads. Lignite gasification can yield other very useful by-products including (i) dephenolized cresylic acid used in the production of industrial solvents, industrial resins and antioxidants, as well as in the manufacture of pesticides, disinfectants, perfumes and preserving agents; (ii) Catechols, used to manufacture pharmaceuticals, insecticides and food flavoring; (iii) Naphtha, used in the production of gasoline and benzene, as well as a fuel for camping equipment, a cleaning fluid, an ingredient in shoe polish and even a medium in oil painting; (iv) Phenol, used to manufacture the resins that bond plywood together and is also used in the casting industry,

The coal can equally be processed to smokeless briquette for domestic purposes e.g. home warming, cooking, etc. This will reduce the desertification problem caused by deforestation by firewood sourcing. The use of smokeless coal briquette is highly recommended for Nigeria especially the northern part where the problem of deforestation is overwhelming. The low value of sulphur and nitrogen contents in the brown coal samples makes it friendly to the environment. Hence, limited $\mathrm{NO}_{2}$ and $\mathrm{SO}_{2}$ gases will be released to the environment during combustion. 


\section{CONCLUSION}

Geochemical characteristics of the lignite seams of the Ogwashi-Asaba Formation in the Niger Delta Basin outcropping in Anambra State, southeast of Nigeria were investigated to evaluate the quality and possible benefits for industrial purposes. The lignite in the study area can be used for electricity generation, coal combustion and coal gasification byproducts. Lignite generated electricity is abundant, low cost, reliable and environmentally compatible. Although the studied lignite deposits are ranked as low-quality coals, their quality can be improved when beneficiated, and used for powering of trains (not in modern times), and production of briquettes, cement, paper iron and steel. The high ash content of the samples may contain variety of concentrated heavy metals, including many known carcinogenic and neurotoxin chemicals. If consumed or inhaled, the toxicants can cause several kinds of diseases to human being like cancer, kidney disease, gastrointestinal illness etc. Ash, as a solid waste material, is generated due to coal combustion. Toxic constituents of coal ash create poison into air, land and human drinking water and pollute them while blowing, spilling and leaching (dissolving and percolating) from storage units.

The ultimate analysis indicates that the coal samples from Amaiyi, Oruru, Obiakoloma, Ekulo stream and Eze stream possesses moderately low carbon and hydrogen and relatively low sulphur and nitrogen contents. Thus, by comparing the properties of the coals, the majority of the analyzed coal samples are suitable for power generation, iron and steel making, cement production and feedstock for chemicals. Amaiyi stream, Oruru stream, Obiakoloma stream, Ekulo and Eze stream brown coal samples are the best for cement production due to their high volatile and mineral matters.

Lignite is an important component in both local and national energy budgets in several parts of the world, despite its lower heating value. A few setbacks can frustrate the efforts to exploit lignites within this vicinity. They include the volume of the material in relation to its heating value, the high-moisture content lowers the energy density of the fuel and makes its transportation uneconomic over long distances, community issues and problem with substitution was that the various qualities of brown coal had to fulfill several different industrial requirements.

\section{ACKNOWLEDGEMENT}

The authors (CFRO and OCO) thankfully acknowledge TETFUND, and COOU for the Institution Based Research (IBR) fund released for the study. The authors also acknowledge the National Geosciences Research Laboratory of the Nigerian Geological Survey Agency for the laboratory studies. They are also grateful to the Department of Geology, COOU and the various communities in the study area for logistics during fieldwork.

\section{REFERENCES}

Acra, E.J., Jackson, C.A., Omoboh, J.O., Omigie, J.I., Ikporukpo, B. T.J. and David Inyang. (2014), "Provenance studies and sedimentology of Ogwashi-Asaba Formation, Anambra Basin, Nigeria", International Journal of Science inventions today. 3 (5): 538- 555.

Afonja, A.A., (1996), "Production of Metallurgical Coke from Non-Coking Coals. In: Nigerian Coals", A Resource for Energy and Investments, Afonja, A.A. (Ed.). RMRDC, Abuja, Nigeria, pp: 89-105.

Ahiarakwem, C.A., and Opara, A.I. (2012),"Some Geochemical properties and industrial applications of Lignite Deposits; case study of orlu and environs, Southeastern Nigeria", International Advanced Scientific Research and Technology Journal. 1(1): 3-10.

Akande, O.A., (1986), "Nigeria mineral deposits, guides and prospects",Unpubl. Inaugural lecture to Nigeria Association of Geosciences and Mining Students (NAGAMS), 9 p.

Akande, S.O, Adeoye, M.O and Erddmann, B.D., (2015) "Petroleum source rock potential assessment of the Oligocene-Miocene Ogwashi-Asaba Formation, southern Anambra Basin, Nigeria”, PTDJ, 5 (1): 4 - 34.

Akande, S.O., Hoffknecht, A., \& Erdtmann, B.D., (1992)," Rank and petrographic Composition of selected upper cretaceous and tertiary coals of Southern Nigeria”, Int. J. Coal Geol., (71): 209-224

Bassey, C. and Eminue, O., (2012), "Petrographic and stratigraphic analysis of Paleogene Ogwashi-Asaba Formation, Anambra Basin., Nigeria", NAFTA, 7 - 8: 247 - 254.

Berkowitz, N., (1979)",An Introduction to Coal Technology", Academic Press Inc., London. 34.

Calkins, W., (1994), "The chemical forms of sulfur in coal: a review”, Fuel 73: 475-484.

Chene, Jan du R.E., M.S. Onyike and M.A. Sowunmi, (1978), "Some Eocene pollen of the Ogwashi-Asaba Formation, Nigeria", Revista Espanol Micropaleontol., 10: 285 - 322.

Chukwu, M., Folayan, C.O., Pam, G.Y., \&Obada, D.O., (2016), Characterization of Some Nigerian Coals for Power Generation.J. Combust., 1-11.

De Swardt, A.M.J. and H. Piper, (1957) ,'The lignites of Asaba division, Benin province", Records of the Geological Survey of Nigeria, 5-23.

Dobrogorskii, N.,(1981), “Quality of Coal Ash and Its Utilization”,VichtaShkola, Kiev, 118 pp. (in Russian).

Du Preez, J.W., (1945), "Geology of Oba and Nnewi lignite deposits, Onitsha Province”, Annual report of Geological Survey of Nigeria, 26-29. 
Ejeh, O.I., Akpoborie, I.A., Etobro, A.A.I., (2015),’Depositional setting of sandstones from Oligocene-Miocene Ogwashi-Asaba Formation, Niger Delta Basin, Nigeria, Evidence from grain size analysis". Universal Journal of Geosciences, 3(3): $71-82$.

Environmental Impacts of Fly Fly Ash Generated from a Coal Fired Power Plant in Indian Sub-Continent, WriterSomesh Jena, Department of Civil Engineering, National Institute of Technology, Rourkela, India.

Eskenazy, G., (1970), “Ash distribution in coals from Maritza-East basin”, Comtes Rendus de l'Academie Bulgare des Sciences, 23: $1127-1130$.

Finkelman, R., (1988),"The inorganic geochemistry of coal: a scanning electron microscopy view", Scanning Microscopy, 2: 97-105.

Inaner, H., (2005), "Properties of lignites from Konya - Ilgin - Cavuscu deposit and its potential use in a future power plant (Turkey)", Bulletin of Geosciences, 80 (1): 19 - 22.

Jauro, A., M.O. Agho, O.J. Abayeh, N.G. Obaje and M.B.J. Abubakar, (2008), "Petrographic study of coal in the Benue trough", Mining Geol., 44: 11-18.

http://www.authorstream.com/Presentation/chintoo-146767-coal-ppt-1-teamcoal-educationpowerpoint/An introduction to coal. [Accessed 21-01-2012]

Li, Z., Ward, C.R., Gurba, L.W., (2010), "Occurrence of non mineral inorganic elements in macerals of low-rank coals. "International Journal of Coal Geology, 81: 242-250.

MOMSD, (2007), Ministry of Mines and Steel Development of Nigeria (MOMSD), (2007), http:/ msmd.gov.ng/about msmd/profileMinistry.asp.

Nicholls, G.D., (1968), The geochemistry of coal-bearing strata. In Murchison, D., Eestall, T. (Eds), Coal and Coal bearing strata. Oliver and Boyd, $269-307$.

Nwadinigwe, C.A., (1992), "Wax and resin characteristics of Nigeria's lignites and sub-bituminous coals". J. Min. Geol., 28: $75-80$.

Nwajide, C.S., (1979), “A lithostratigraphic analysis of the Nanka Sands, South-eastern Nigeria”, Journal of Mining and Geology, 16: 100-110

Nwajide, C.S.,(1980), "Eocene tidal sedimentation in the Anambra Basin, southern Nigeria", Sediment. Geol., 25 : $189-207$.

Nwajide, C.S., (2013),’Geology of Nigeria’s sedimentary basins",. CSS Bookshops Ltd., Lagos, 565p.

Oboh-Ikuenobe, F.E., Obi, C.G. and Jaramillo, C.A., (2005), "Lithofacies, Palynofacies and sequence stratigraphy of Paleogene strata in South-eastern Nigeria”, Journal of African Earth Sciences, 41, 79-102.

Odumodu, C.F.R. and Onyemesili, O.C.,(2021), "Eocene Stratigraphy and Industrial potentials of lignite deposits in Anambra State, Nigeria", Oriental J. Sci \& Engr., 2 (1): 1 - 20.

Ogala, J. E.,(2011), Source rock potential and thermal maturity of the tertiary lignite series in the Ogwashi-Asaba Formation, Southern Nigeria. Asian J. of Earth Sci., 4:157-170.

Ogala, J.E., (2012), The geochemistry of lignite from the Neogene Ogwashi-Asaba Formation, Niger Delta Basin, southern Nigeria. Earth Science Research Journal. 16 (2): 151 - 164.

Okeke, K.K. and Umeji, O.P., (2018),. "Palynofacies, Organic Thermal Maturation and Source rock evaluation of Nanka and Ogwashi Formations in Updip Niger Delta basin, Southeastern Nigeria”,. Jour. Geol. Soc. India, 92: $215-226$.

Okezie, C.N. and Onuogu, S.A., (1985), The lignites of Southeastern Nigeria: A summary of available information. Geological Survey of Nigeria occasional paper, 10:1 - 16 .

Olobaniyi, S.B. and J.E. Ogala, (2011), “Major and trace element characteristics of the Tertiary lignite series within the Ogwashi-Asaba Formation, southern Nigeria". Proceedings of the 23rd Colloquium of African Geology/14th Conference of the Geological Society of Africa Johannesburg, January 8-14, 2011, South Africa, -

Onyekuru, S.O., Iwueke, E.L., Ikoro, D.O., Opara., K.D. and Fagorite, V.I., (2019), “The stratigraphic significance of lignite deposits in parts of Orlu, southeastern Nigeria”, Int. Jour. of Inno. Env. Studies., 7 (3): 1 - 11.

Reyment, R.A., (1965), “Aspects of the Geology of Nigeria”,.Ibadan University Press, 145 p.

Sahni, A., Saraswati, P.K., Rana, R.S., Kumar, K., Singh, H., Alimohammadian, H., Sahni, N., Rose, K.D., Singh, L., and Smith, T., (2006), "Temporal constraints and depositional paleoenvironments of the Vastan lignite sequence, Gujarat Analogy for the Cambay Shale hydrocarbon source rock”. Indian Jour. Petrol. Geol., 15, pp. $1-20$.

Schopf, J.M., (1960), "Field Description and Sampling of CoalBeds",. U.S. Geological Survey bulletin 1111B.United state government printing press office Washington, 25-70.

Short, K.C. and Stauble, A.J., (1967), Outline of Geology of the Niger Delta. AAPG Bull. 51: 761-779.

Simpson, A., (1955), "The Nigeria Coalfield Geology of parts of Owerri and Benue Provinces", Geology Surv. Nigeria Bull. 24: 1-85.

Stach, E., Mackowsky, M., Teichmuller, M., Taylor, G., Chandra, D., Teichmuller, R., (1982). Stach's Textbook of Coal Petrology. Gebruder Borntraeger, Berlin, 535 pp. 
Swanson, V.E. and Huffman, Jr C., (1967). "Guidelines for Sample Collecting and Analytical Methods Used in the U.S. Geological Survey for Determining Chemical Composition of Coal”. United States Department of the Interior, 1-10.

Umeji, O. P., (2003) "Palynological Data from the Roadcut section at Ogbunike Tollgate, Onitsha", Southeastern Nigeria. Jour. Mining Geol. 39 (2): 95 - 102.

Vassilev, S., Kitano, K and Vassileva, C., (1996), "Some relationships between coal rank and chemical and mineral composition", Fuel, 75: 1537 - 1542.

Wilson,R.C., (1924), "Brown coal in Nigeria". Occasional paper number 1 of Geological Survey of Nigeria. Government of Nigeria, 1-15. 